\title{
The politics of (im)mobility: Rickshaw bans in Dhaka, Bangladesh
}

\author{
Md. Musleh Uddin Hasan ${ }^{a^{*}}$ and Julio D Dávila ${ }^{\mathrm{b}}$ \\ ${ }^{a}$ Department of Urban and Regional Planning (URP), Bangladesh University of Engineering and Technology (BUET) \\ bevelopment Planning Unit (DPU), University College London (UCL)
}

\section{Introduction}

Urban transport interventions, particularly in developing countries, increasingly focus on promoting Motorized Transport (MT) at the cost of Non-Motorized Transport (NMT). Despite having favorable features - compact urban structure and mixed land use - for developing Non-Motorized Vehicle (NMV) and walking focused transport infrastructures, many cities in Asia (Imran and Low, 2003; Enoch, 2003; Low \& Banerjee-Guha, 2003) and Africa (Sietchiping et al, 2012; Gondo, 2010) and in the Global South are making wild investments in auto-oriented urban and transport infrastructures. Ahmed \& Shi Ye (2008:126) show that such developments in Chinese and Pakistani cities in many cases compromise environmental sustainability, long term feasibility, social equity and favor "a minority of premium modes users over a majority who prefers walking, biking and conventional transit system". Public transport systems in Delhi, India, as well, exclude these users, who remain outside the formal planning process and is not "taking care of the slow vehicles [NMVs] on the road" and hence, is functioning in a sub-optimal condition (Tiwari, 2002:95). In case of African cities, Khayesi et al (2010) find similar levels of negligence towards pedestrians, cyclists and street vendors in transport policy and practice in Nairobi, Kenya. They show that this results in competing use of pavements and roads which ultimately exposes pedestrians, cyclists and street vendors to insecurity and harassment. In Bangkok, the Skytrain has contributed to increase social inequality by providing an alternative mode for an 'idealized' (new type) user, thus ignoring the unaffordable majority (Richardson \& Jensen, 2008).

This is a common feature in a growing generation of urban mega-projects in the Global South (ibid); more frequent are large investments in roads and elevated motorways than rail-transit systems or mass-transit systems like BRTs. Thus, urban 'soft mobilities' are eliminated in favour of auto-mobility resulting in a "spatial organization and mobility regime incongruent with widespread transit, pedestrian and bicycling spaces" (Henderson, 2004:203).

NMT is "the neglected Cinderella of transport modes" (Gwilliam, 2003:212) and is "systematically underrecognized" (World Bank, hereafter WB, 2002:xiii). Rahman et al. (2009) have expressed serious doubt regarding the future of popular NMVs - rickshaw, becak, etc - in Asia. NMT detractors depict these NMVs as being degrading and slow while causing congestion and argue for bans. Hence, bicycles and rickshaws are banned in many Chinese cities (Zacharias, 2012) as well as in an increasing number of Indian cities: Delhi in the 1980s (Ravi, 2012) and then in Calcutta (Sen, 1996). Bans are also put forth in other Asian cities: Jakarta since the 1980s (Rahman et.al. 2009); Kuala Lumpur (Hook \& Replogle, 1996); Bangkok since 1962 (ibid); Karachi since 1969 (Gallagher, 1992); Manila since the 1950s though they re-emerged in the 1980s (Replogle, 1991). Bans have also been recorded in other countries of the Global South 
including Africa (WB, 2002; Gwilliam, 2003). The latest additions to this growing list are Bangladeshi cities: Dhaka (Bari and Efroymson-hereafter B\&E, 2005a, 2005b; Rahman et al, 2009) - the last capital city which is having rickshaws and also Chittagong.

Thus, access to mobility options is becoming a matter of choice for some, for others it is a question of fate (Albertsen \& Diken, 2001 quoted in Sager, 2006). Such decisions are highly politicized resulting in 'unjust mobilities' (Hasan, 2013). The issue can be studied at least from three perspectives: users, NMV operators (drivers and owners) and decision makers. This paper focuses on the last perspective and examines the role of power in decision-making, process of negotiations and implementation in this regard. However it does not list out or investigate all anti-NMT logic(s) put forwarded. Rather this article asks the following questions: is this anti-NMT trend an outcome of an objective transport planning process or decision(s) of some other else? Who takes the decisions and why? Are the deciding actors isolated or connected? If connected, what is the scale of their connection - local or global? How and why does the connection sustain? Taking the case of complete and partial ban on the movement of rickshaws- a human-pedalled tri-cycle generally carrying two persons-, in Dhaka, Bangladesh, seeks to answer the questions posed above.

\section{The politics of mobility - A review of theories}

This paper reflects on the exercise of power and existence of (in)justice in (transport) decision making process. It draws from the theoretical premises of political economy and informality. Following Cresswell (2010:21), politics is meant to be as "social relations that involve the production and distribution of power" and politics of mobility as "the ways in which mobilities are both productive of such social relations and produced by them". Politics of mobility also represents political struggles over modes and urban configuration and in a broader sense, an extension of ideologies and normative values about how cities should be configured and by whom (Henderson, 2004). It ultimately leads to "considerations over rights to mobility" (Jensen, 2011:257), including questions: mobility for whom and at what cost and conditions? (Sheller, 2008).

In fact, decisions to ban (rickshaw), what is seen to be antiquated, non-modern vehicles arise out of a complex set of decisions informed by values and arising from pressures from interest groups. Therefore, studies in urban politics and justice need to account for the various actors implicated in the process through polymorphic, multidimensional, and complexly interwoven social agencies and spatial practices. Harvey (1982, 1996), Logan and Molotch (1987) have shown how the contestation of urban space is (actually and essentially) an extension of struggles over differing values and ideologies. But it should be remembered that "just as the economy involves more than buying and selling consumer goods, so the polity involves more than the pressures and counter-pressures on discrete policy choices" (Stone 1982:276). Decisionmakers and decision-making bodies do not act in a vacuum but are rather part of a broader social system managing a set of possibilities and constraints (Zunino, 2006). Such policy decisions in an urban context do not arise from the domination of a single elite but rather the interaction of many different (public and 
private) interests which lead a group to exercise power in urban decision making (Dahl, 1961; Mollenkopf, 1983; Stone, 1989, 1993).

In contrast to the pluralist view espoused by Dahl and others, structuralists are primarily concerned with the economic and functional limits of local government and primarily consider the power of (local and global) capital in shaping the politics of urban development (Strom, 1996; Sassen, 1991). The process, as Feagin and Smith (1987:5) observe, can best be understood by analyzing cities in terms of their "transnational linkages ... within the world capitalist economy, its multinational firms and its processes of economic restructuring". Molotch (1993:31) concludes: "[c]oalition with interests in growth of a particular place (large property holders, some financial institutions, the local newspaper) turn government into a vehicle to pursue their material goals". Again, Shefter (1985), Elkin (1987), Stone (1989, 1993), Mollenkopf (1983) embrace pluralist understanding of (private and public) interest articulation and coalition building without completely abandoning structural (economic and institutional) constraints giving way to the 'regime theory' in urban politics. Urban regime analysis emphasizes social stratification as a source of social and economic coalition building and explores how they work against open and penetrable arrangements which are relatively stable, cross-sectoral, informal and productive (Stone, 2005, 2001).

Proponents of theories of informality argue that it has serious implications in decision, decision making process and associated politics in an urban context. De Soto $(1989,2000)$ defines informality as "extralegal behaviour", in between legality and illegality, of stakeholders whose ends are legal but means are proscribed by inefficient bureaucracy, exorbitant charges, unjust laws, or arbitrary administrative decisions. Again, in context of expanding urban informalities worldwide, Yiftachel (2009) shows 'gray spaces' always exist between the 'whiteness' of legality, approval and safety; and the 'blackness' of eviction, destruction and death; governments use these 'gray spaces' to eliminate what they think unwanted. Thus it is the 'gray space' of informality that helps the powerful or their allies to take 'extralegal' advantages which, in many cases, cost and cause miseries to the general and marginal stakeholders. It is argued that "the rich and powerful" take more benefits "than the poor" using the informal windows and scopes (Bromley, 2004:277) and the "techniques of informalization simultaneously enable and stall projects of populism and developmentalism" (Roy, 2004a:160).

\section{Methodology}

The paper draws heavily on existing literature including government plans while summarizing the history and context of bans. Relevant stakeholders engaged, directly or indirectly, in supporting, facilitating or opposing rickshaw ban decisions were interviewed: six academics doing research and providing advisory or consultation services to the government and private agencies; two officials at Dhaka Transport Coordination Authority (DTCA, previously known as Dhaka Transport Coordination Board, DTCB) - a planner, a transport engineer; an official from the then Dhaka City Corporation (DCC); one former Minister of transport and communication; a journalist; a citizen rights activist; a rickshaw garage owner 
(hereafter rickshaw owner). The semi-structured interviews started simply with questions about mobility condition in Dhaka and associated problems and solutions. Later on their views regarding rickshaws in Dhaka were explored. Finally, they were particularly asked about their experience with and interpretation of interventions to ban rickshaws on different occasions. Based on the notes and memos of the interviews emergent themes regarding the motive and context that led to rickshaw bans were identified. Cross analysis was made with other interviewees, literature and by interviews of two rickshaw-drivers (rickshaw-wallas) and a rickshaw rider (user). The rickshaw-wallas used to ply their rickshaws in the currently rickshaw banned areas, namely (i)Shukrabad, (ii)Shyamoli and the rider was from another rickshaw restricted area Segunbagicha (Map 1).

Based on literature and interviews the time line of the ban and restriction events and their contexts are chronologically summarized (see Section 5). In Section 6 an actor analysis is done. Finally, in Section 7 the key features and factors that help and facilitate to persist the politics leading to rickshaw bans in Dhaka is discussed.

\section{Why do rickshaws matter in Dhaka?}

Before getting into details, it is an imperative to explain why rickshaws matter in the life of citizens in Dhaka and to what extent it is important among the transport modes and NMT modes. Many studies on rickshaws in Bangladesh (and India) - Begum and Sen (2004), Ali (2013) for example - and almost all the transport planning and decision documents for Dhaka, see Section 5, understand the importance of rickshaw from informal labour market, rural-urban migration and poverty perspective. Hence, being oblivious of the role of rickshaws in carrying million passengers every day, a large number of literature propagate the engineering arguments against rickshaws terming the mode slow moving, space occupying, not suitable in a mixed mode road, etc. (See literature by Bari and Efroymson, referred in this article, for a full account of such arguments). A few also put forward health (and wellbeing) argument against rickshaw: Begum and Sen (2004). On the contrary, a growing number of literature is highlighting usefulness of rickshaws: Hossain and Susilo (2011), Hasan (2013) from social equity perspective; Gallagher (1992) and literature by Bari and Efroymson from transport planning perspective - they also refute engineering arguments; Goyal and Asija (2015) environmental perspective; Islam (2015) from art and aesthetics perspective.

True that rickshaws are found in many cities around the world: in Europe, America and Japan only tourists use them; in many South and South-East Asian cities it is widely used as a transport mode (Gallagher, 1992). However, the number of rickshaws in Dhaka will stun any visitor (Kalabamu, 1987); Dhaka is known to be the 'rickshaw capital of the world' - several online campaigns promote this image of Dhaka (Internet 1 to 4); there is no accurate estimate of its number (STP, 2005a:7). DCC stopped issuing licenses to rickshaws in 1979 when their number was 79,554 (Interview 1). Current unofficial estimates place the figure between 0.8 million and 1.1 million, with about a million considered illegal (Daily Star,-hereafter DS, 2012, quoting Dhaka Metropolitan Police (DMP) Traffic Commissioner). The volume of passengers 
transported is equally stunning - 7.6 million person-trips per day in 2009 (JICA 2010;3-15), close to double the highest number of passengers carried (4.4 million) by London Tube in a single day during the 2012 Olympics (Metro, 2012). The share of rickshaw trips is also overwhelming in 2015, for 3.25 million total daily trips shares for rickshaws, car, foot and public bus were 37.69\%, 7.22\%, 17.72\%, and 36.97\% respectively (RAJUK, 2015: 93).

In 2009, average length of rickshaw trips and all trips were $3 \mathrm{Km}$ and $7.7 \mathrm{Km}$ (JICA, 2010: 4-15 \& 12-7) i.e. all short trips and many of the medium length trips can be covered by rickshaws. Figure 1 shows that in 2009 rickshaws served highest 38.7\% of all trips for all income groups in Dhaka. Distribution of rickshaw users across different income group shows that in 2009, 35\% of all trips by high income groups were made by rickshaws, while it was $42 \%$ and $47 \%$ for middle and low income groups. Again, rickshaws are important for each purpose-based trip. Figure 2 shows that in 2005, it was the main mode used for 'home-education' trips (42\%) and second highest mode used for 'home-work', 'home-other' and 'nonhome based' trips.

Figure 1 shows that rickshaw and walking i.e. NMTs in total share more than $50 \%$ of all trips for medium and low income groups and slightly below one half for high income groups. Similarly, Figure 2 shows that NMTs share more than $50 \%$ of 'home-education' trips, and less than $50 \%$ of 'home-work' and 'homeother' trips. On the contrary, cars share only 5.2\% of total trips by all income groups; $1.5 \%, 4 \%$ and $17.5 \%$ for low, medium and high income groups respectively (Figure 1). In case of purpose based trips, car trips are below $10 \%$ for all types, except for non-home based ones. Therefore, rickshaw is as equally important for all income groups and for all types of trips in Dhaka.

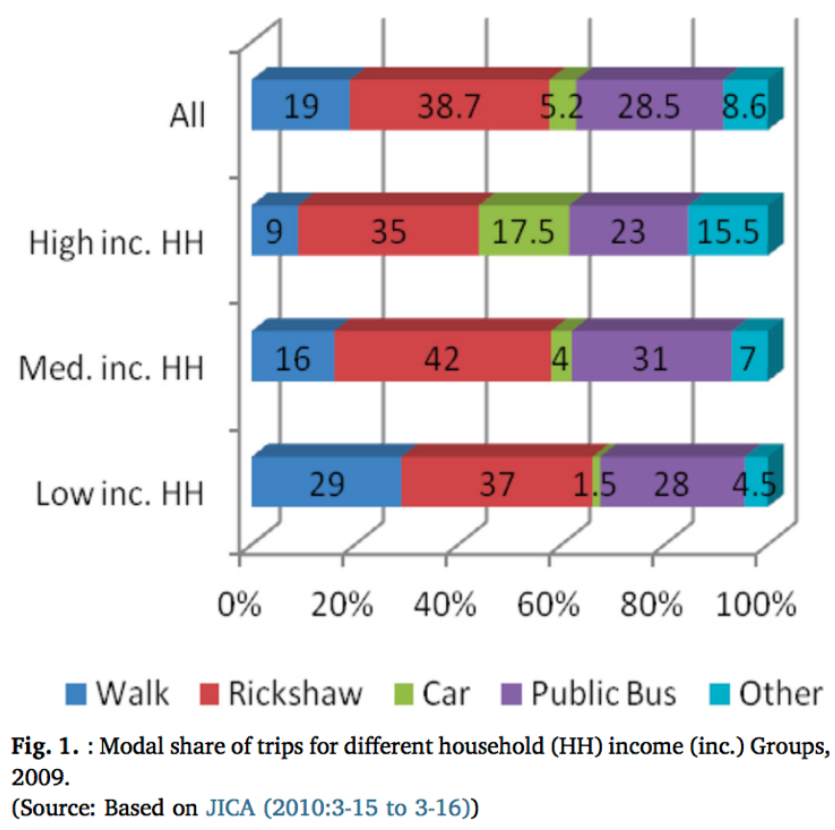




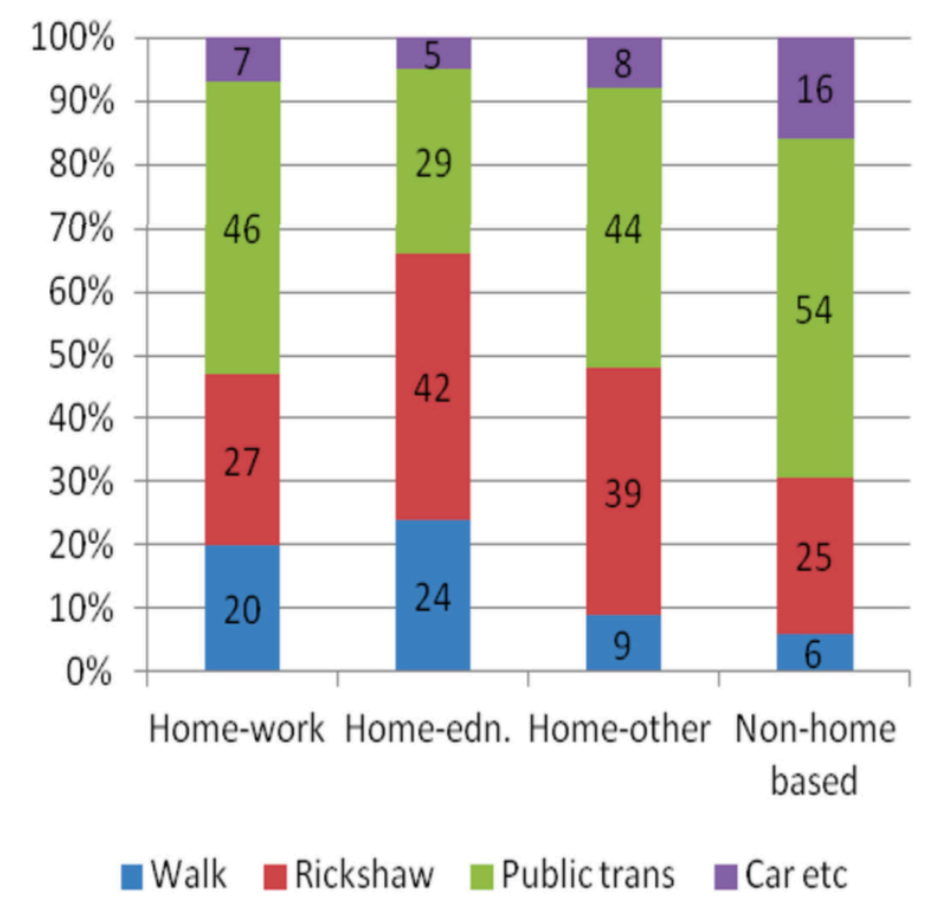

Fig. 2. Modal share in each purpose based trips, 2004.

(Source: Based on STP (2005a:12))

So, as far as trip characteristics are concerned, there is no obvious reason why NMTs, rickshaws in particular, should be pushed aside in transport plans and interventions in Dhaka. In fact, despite priority on auto-oriented development and increasing motorization in recent decades, Dhaka is still one of the least motorized cities in the world (WB, 2002:7) with approximately 32 vehicles/1,000 residents (STP, 2005b:20). Moreover, rickshaws suit well in densely built-up areas in Dhaka (Kalabamu (1987; Majumder, et. al 2009).

\subsection{Service operation of rickshaws in Dhaka}

The rickshaw industry and its related service are almost entirely regulated by rickshaw (garage) owners. In 1988, Gallagher (1992:462) found that around 10\% of the rickshaw-wallas owned rickshaws. But, interviews, in 2012, with rickshaw-wallas, rickshaw owners and experts for this research, put the estimate to $2 \%$ to $4 \%$. The owners have their own garages where they keep these rickshaws. The rickshaw owner may range from small (with 10 to 15 rickshaws) to big (with as many as 1200 rickshaws) (Interview 2). Owners have several associations; Nayadiganta (2012) reports the number to be 28. Most of the associations are patronized by political parties (Gallagher, 1992:557). While these associations have little success in putting forward and realising the interest of rickshaw-wallas, they are more involved in selling illegal 'number plates' to the rickshaw-wallas or owners. Several such organizations sold 8,000 'number plates' during 1986 rickshaw ban period (Gallagher, 1992:578) and 43,000 plates during 2002 ban period (Interview 1) with the same promise that the holders will be given legal license. In the first case they were successful (Gallagher, 1992:578), but for the next, not. 
A rickshaw-walla rents a rickshaw from the owners for driving it half a day or the whole. It is the owners and their associations who decide the conditions for renting rickshaws. The rickshaw-wallas, who are mainly illiterate and in many cases seasonal migrants in Dhaka, have no say in fixing the rent, nor do they have any association of their own. Hence, if bans or restrictions are imposed, rickshaw-wallas simply avoid the roads off-limit to them, unless the owners' association decide to protest (Interview 3). Similar to number of rickshaws, there is no accurate estimate of rickshaw owners and rickshaw-wallas in Dhaka (Interview 1, 2, 3). There is also no government control over rickshaw fare, as such no fixed fare. From interviews with rickshaw-wallas and rider it has been found that if owners increase the rent or if extra length has to be travelled due to rickshaw ban or restriction in specific roads, rickshaw-wallas charge extra charge according to what they think proper.

\section{Timeline of bans and restrictions on rickshaws and associated transport policies, plans and studies in Dhaka}

This section presents a chronology of bans and restriction on rickshaws in Dhaka based on literature and interviews of experts. It also briefly discusses how the ideas and decisions for bans and restrictions were initiated and implemented. The logics, which are basically engineering arguments against rickshaws, put forward in official documents behind off-limiting rickshaws are also highlighted.

\subsection{The 1980's and earlier - bans at the whims of individuals, without scientific study}

Attempts to ban rickshaws in Dhaka are not new. A veteran academic tells of attempts in 1960s (Interview 4). Ban was imposed in 1981 in Motijheel, but lifted following street demonstration and barricades by a 'union' of rickshaw owners (Gallagher, 1992:569-571). (Map 1 \& 2 show that at Motijheel rickshaws are still plying). The first successful closure was on Airport Road in December 1986 when it was declared 'VIP road' as the President - a military dictator - wanted his way to and from the airport to be free-flowing (Gallagher, 1992:578-81). However another plan in 1987 to completely ban rickshaws in Dhaka on "safety grounds" never succeeded (Rahman, et. al., 2009).

\subsection{The 1990's - preparing ground for bans under the cover of donor driven policies}

In 1992, UNDP supported the Dhaka Integrated Transport Study (DITS), first of its kind in Dhaka. The very first page of DITS report is notable: "many observers have commented on the need to various forms of transport infrastructure development from fly-overs to high capacity commuter rail systems... [A] shortage of development funds has held back the implementation of such capital intensive proposals". On one way, DITS proposed segregation from MT, licensing all rickshaws, insuring rickshaw-wallas, etc., on the other hand, it proposed to keep the primary roads "open only for motorized modes" (DITS, 1994a:119131). The syllabus of the DITS fellowship programs in Australia and Thailand for Bangladeshi officials 
(DITS, 1994b:K-1-K-3) did not include NMT or rickshaws; cities visited as part of study tours (ibid:L-1) were those which had 'systematically' destroyed NMT .

WB-financed US\$234.2 million (WB, 2005) Dhaka Urban Transport Project (DUTP) came in 1996 with quite clear philosophy: "the "[d] evelopment of the economy of Bangladesh will depend on it attracting ... global investment. Dhaka, as the nation's gateway ... must be provided with a reliable, secure and comfortable transport system if it is to compete successfully with other major cities" (GoB, 1999:32). Interestingly, the very first Public Consultative Meeting of DUTP-Phase-1 proposed phased withdrawal of rickshaws from 200Km length of roads (UN-ESCAP, 1997:7-1). To increase average auto speed from $15 \mathrm{Km} / \mathrm{hr}$ to $30 \mathrm{Km} / \mathrm{hr}$ (ibid:72) DUTP distributed budget mainly for two items: building road infrastructure (76\%), equipment purchase (5\%) - mostly for DMP (WB, 2005; JICA, 2010). There were also few measures for introduction of new buses and routes, and for development of NMT zones (ibid); but those were never implemented (Interview 5). Moreover, the automated signals installed lacked synchronization for NMTs (B\&E, 2005a:18-19).

\subsection{Early $21^{\text {st }}$ century - Bans in multiple corridors and more plans and strategies}

In 2002, DCC initiated, as part of DUTP, the implementation of the "NMT-Free Arterial NetworkPhased Implementation Plan" (STP, 2005:3-4) for phased withdrawal of rickshaws from 11 major roads (Map 1) (WB, 2005). Mirpur Road (Gabtoli-Russell Square) and Panthapath (Russell Square-FDC) was made rickshaw free in December 2002 to increase the average speed on the roads (New Age, 2005).

Initially to compensate the problems of the rickshaw riders some segments of the corridors had separate rickshaw lanes. But later on they were abandoned. A rickshaw-walla remembers and explains: "as the rickshaws were innumerable, there were always long queues which spread beyond the lanes and clogged the intersections. So many rickshaw-wallas used to move on to the auto lane. At times passengers also insisted to defy the lane rule. Traffic police got very rude with us at times, but let loose when got tired in an unreasonable war. Ultimately NMT lanes in many roads were abolished followed by a full ban of the rickshaws in those segments" (Interview 6). In fact, there was no improvement in auto-mobility (DSM Consultants, 2006), rather new problems arose in other roads where rickshaws were diverted (Majumder, et al., 2009). Led by owners' association leaders, rickshaw-wallas demonstrated in front of the National Press Club; and civil society bodies organized several discussion meetings (Efroymson and Bari-hereafter E\&B, 2005). The WB Resident Mission Chief in Bangladesh was contacted and informed regarding public miseries (Interview 5). Finally, the WB withdrew its support in 2005 (New Age, 2005; WB, 2005). 


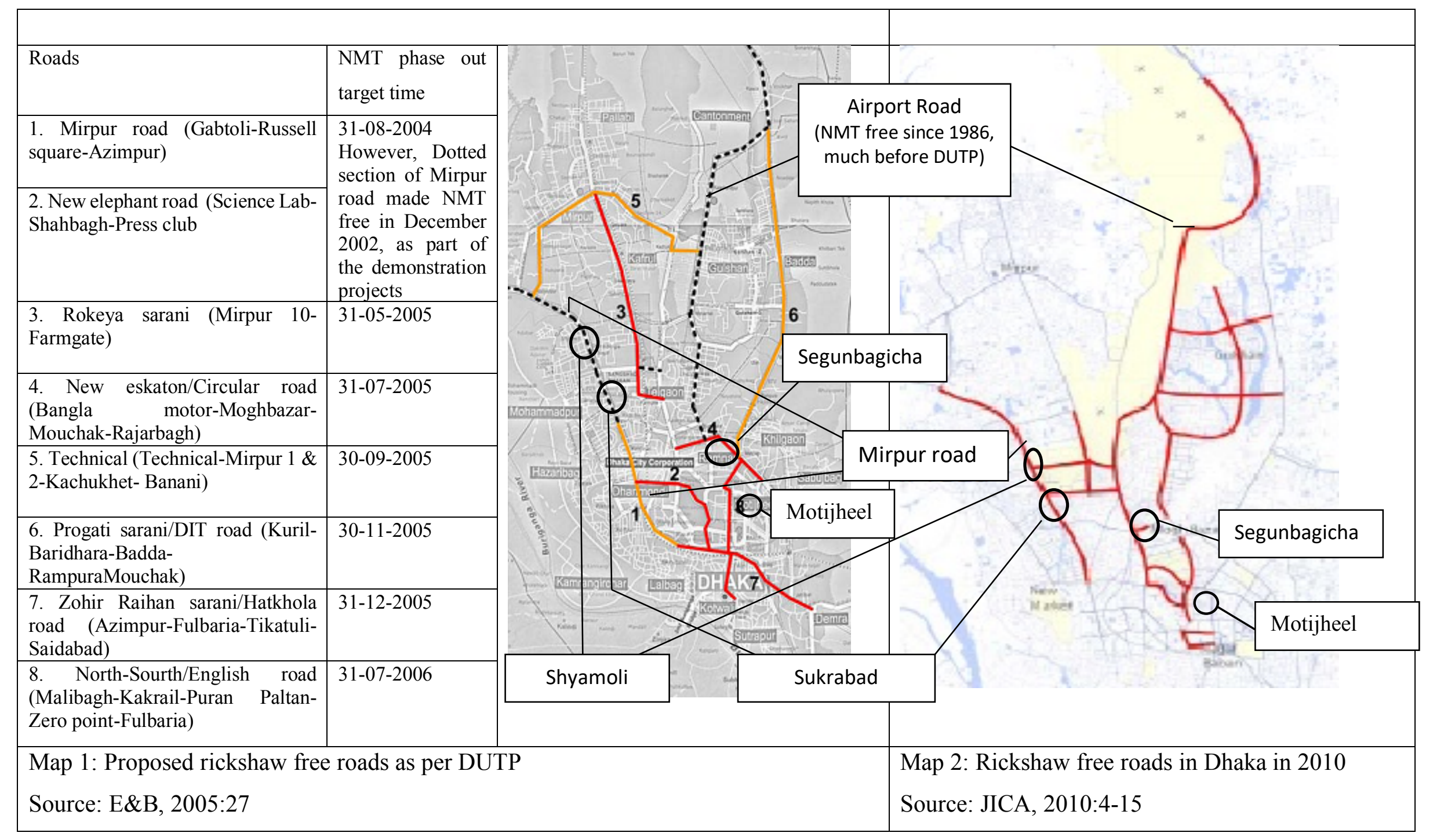


Meanwhile, National Land Transport Policy-2004 argued for the continuation of a 'progressive ban' of rickshaws on major roads, aiming to reduce rickshaw trips by half by 2014 and envisaged to allow car trips upto $30 \%$ of all mechanised trips in 2022 (GoB, 2004:32-42) which was 9.94\% in 2009 (JICA, 2010).

After withdrawal from rickshaw ban plan, WB financed DTCA to prepare Strategic Transport Plan (STP) 2004-2024 with major objective to establish a sound policy framework for sustainability of current and future investments in the transport sector (JICA, 2010:10-6). US\$ 5,519 million in STP projects (JICA 2011:10-8) were distributed as follows: metro (serving $8 \%$ of all trips)-63\%, car-friendly projects including expressway30\%, Bus Rapid Transit (BRT)- 6.27\%, bus-0.41\%, pedestrian- $0.24 \%$ and rickshaws-0.24\% (B\&E, 2008:6).

Based on STP, JICA came forward for the Dhaka Urban Transport Network Development Study (DHUTS) with a claim to "open new era of innovative transport system in Dhaka ... based on lessons learnt from many [Asian] cities ...[with] Mass Rapid Transit (MRT) system as a backbone of transport system" (JICA, 2010:E6-E-7). Meanwhile, DTCB and DCC launched WB-financed Clean Air and Sustainable Environment (CASE) project in 2009 (JICA, 2010:10-12) for traffic safety, separation of MT and NMT and design of BRT. Although, no project for NMT is on the field, several MRT, BRT, flyover projects are underway. But a professor and transport consultant opines: "among [these big projects] the first one implemented will seize the feasibility and engineering possibility for the rests forever" (Interview 7).

\subsection{Latest moves - fragmented restrictions in several roads and locations}

Although the previous plan was never abandoned nor fully executed, it had been learnt that DMP now restricts rickshaws in different intersections or road segments, outside DUTP, to 'decongest' roads for smooth auto flow (Interview 8 not14). As many as 22 roads and eight link roads were off-limit to rickshaws (Map 2; DS, 2012) with the same old argument for increasing the speed of vehicles on those roads. (Therefore, Map 2 has more rickshaw restricted roads or segments than those in Map 1)

\section{Actors and their roles in decisions regarding bans and restriction of rickshaws}

This paper argues that auto-oriented interests have brought under an umbrella a range of actors coalesced in an alliance against rickshaws facilitated by a politics of informal arrangements. An alliance of autocrats, technocrats and auto-lobby makes best use of such politics in a weak democracy. Table 1 shows that, the actors include both institutions and individuals - donors, government (executives and businessmen turned politicians), patron-client based democratic/autocratic political machinery, project related bureaucrats (government/donors), a section of consultants/experts and enterprises (national/international), project/program implementing government agencies- DCC/DMP/DTCB/RAJUK.

Based on interviews of different stakeholders, the roles of the actors are divided into two broad levels:

- Decision making level: (i) reviewing or formulating policy, plans and studies in favor of autos and against rickshaws and (ii) making decision(s) itself. Hence the results of actions by these actors are long-term i.e. delayed, not immediate. 
- Implementation level: (i) identifying potential roads, intersections for ban/restriction and (ii) implementing the decision(s) itself. Hence the results of actions by these actors can be immediately seen or experienced.

Table 1: Actors and their role in the rickshaw bans and restrictions in Dhaka

\begin{tabular}{|c|c|c|c|c|c|c|c|}
\hline \multicolumn{3}{|l|}{ Role } & \multicolumn{4}{|l|}{ Scale } & \multirow{3}{*}{$\begin{array}{l}\text { Actors } \\
\text { (actors in italic are direct } \\
\text { beneficiaries) }\end{array}$} \\
\hline \multirow[b]{2}{*}{$\begin{array}{l}\text { Level of } \\
\text { involve-ment }\end{array}$} & \multirow[b]{2}{*}{$\begin{array}{l}\text { Time lag } \\
\text { between } \\
\text { actions } \\
\text { and } \\
\text { effects }\end{array}$} & \multirow[b]{2}{*}{$\begin{array}{l}\text { Nature of } \\
\text { involve- } \\
\text { ment }\end{array}$} & \multicolumn{2}{|l|}{ Local } & \multirow[t]{2}{*}{ National } & \multirow[t]{2}{*}{ Global } & \\
\hline & & & Area & City & & & \\
\hline \multirow[t]{2}{*}{$\begin{array}{l}\text { Decision } \\
\text { making level } \\
\text { (mostly in } \\
\text { policy sphere) }\end{array}$} & \multirow[t]{2}{*}{$\begin{array}{l}\text { Long-term/ } \\
\text { delayed }\end{array}$} & Strategic & & $\sqrt{ }$ & $\begin{array}{l}\sqrt{ } \\
\sqrt{ } \\
\sqrt{ } \\
\sqrt{ }\end{array}$ & $\begin{array}{l}\sqrt{ } \\
\sqrt{ } \\
\sqrt{ }\end{array}$ & $\begin{array}{l}\text {-Government (Ministers/Member } \\
\text { of Parliament) } \\
\text {-World Bank/Donor } \\
\text { - Bureaucrats (Donor/recipient) } \\
\text { formulating/identifying project } \\
\text {-Experts (National/Int'l) }\end{array}$ \\
\hline & & Passive & $\sqrt{ }$ & $\begin{array}{l}\sqrt{ } \\
\sqrt{ } \\
\sqrt{ } \\
\sqrt{ }\end{array}$ & $\begin{array}{l}\sqrt{ } \\
\sqrt{ } \\
\sqrt{ } \\
\sqrt{ }\end{array}$ & $\begin{array}{l}\sqrt{ } \\
\sqrt{ }\end{array}$ & $\begin{array}{l}\text {-DMP, DTCA \& RAJUK } \\
\text {-Government (Ministers/Member } \\
\text { of Parliament) } \\
\text {-Experts (National/International) } \\
\text {-Businessmen } \\
\text {-Businessmen turned politician }\end{array}$ \\
\hline \multirow[t]{2}{*}{$\begin{array}{l}\text { Implementation } \\
\text { level (non } \\
\text { policy sphere) }\end{array}$} & \multirow[t]{2}{*}{ Immediate } & $\begin{array}{l}\text { Direct } \quad \& \\
\text { active }\end{array}$ & $\sqrt{ }$ & $\begin{array}{l}\sqrt{ } \\
\sqrt{ } \\
\sqrt{ }\end{array}$ & & & $\begin{array}{l}\text {-DTCA \& DCC } \\
\text {-DMP } \\
\text {-Individualized transport using } \\
\text { decision makers }\end{array}$ \\
\hline & & Hidden & $\begin{array}{l}\sqrt{ } \\
\sqrt{ }\end{array}$ & $\sqrt{ }$ & & & $\begin{array}{l}\text {-Rickshaw owners } \\
\text {-Rickshaw Associations } \\
\text {-Influential local persons }\end{array}$ \\
\hline
\end{tabular}

Source: Authors' elaboration based on interviews of experts and other stakeholders

Nature of involvement of actors in "decision making level" is sub-divided as "strategic" and "passive". "Strategic" actors in "decision making level" are the top (political, technical, financial) decision makers or policy formulator regarding role of NMTs. Their decisions have affects at different scales - city, national and global. They also decide the ways to support (financially, legally, by knowledge base) these policy decisions. "Passive" actors provide field information to the policy makers. It has been shared by an interviewee that DTCA, DMP, RAJUK and most of the experts or consultants present at policy/decision making meetings depict the problems in a way that those are created only by NMTs, particularly due to violation traffic rules by rickshaw-wallas; government (ministers, members of parliament) and businessmen turned politicians highlight the 'dream' of a developed city with 'modern' auto-oriented infrastructure and services and without 'old' NMTs (Interview 4).

Nature of involvement of actors in the "implementation level" is sub-divided as "direct and active" participation and "hidden, silent" acceptance. "Active participants" are seen in action from opinion building 
to decision making. DTCA, DCC, DMP and individuals are involved in these tasks to (i) perform official responsibilities; (ii) reap official gain (already stated that DMP received equipments from DUTP); (iii) get relief in organizational responsibility/duty: the less the traffic on roads, the less the official work load for DMP; since rickshaw-wallas are the weakest user of the road and rickshaw is all through overlooked in transport policies and studies, banning or restricting rickshaws is often an easy traffic-ordering tool in the field (Interview 8); (iv) enjoy personal benefits like personal car-based mobility improvement; and (v) gain financially: during 2008-2012 as much as one million 'number plates' were sold by 28 rickshaw associations involving Bangladeshi Tk 400 million of which a part went to DCC and DMP people (Nayadiganta, 2012). (USD 1 equals to Tk 80).

"Hidden and silent participants" are mainly rickshaw owners association, a couple of rickshaw owners and some influential local individuals. They do not publicly speak in favour of bans and restriction, but in a few cases have helped "active participants" identify potential road sections and intersection and 'provoke' them to implement the ban or restriction. A veteran rickshaw garage owner for the last 45 years informed that one large rickshaw garage owner from Moghbazar, who was said to own 1,200 rickshaws, supported restrictions in key intersection of his area to keep away rickshaws from other parts of the city and thus maintained his monopoly in exploiting rickshaw-wallas (Interview 2). In fact, a journalist boastfully described during interview how he compelled the Police Commissioner to ban rickshaws in his area (Interview9). Hence, these "hidden and silent participants" do not oppose but keep silent on decisions regarding bans and restrictions.

Table 1 also shows the scale of operation: most actors are active at national and city scales, some are active globally level and a few are found at localities (neighbourhoods). Many of the actors work in multiple scales and some of them even have overlapping roles at different levels. In case of organizations this is due to their defined roles in different scales and levels and in case of individuals this is due to their access to decision makers or implementers at different scales and levels.

\section{Why and how does the politics of (im)mobility sustain?}

Thus it is clear that there is a 'glocal' (global to local) coalition of multiple actors for promoting auto-mobility and against rickshaw based mobility in Dhaka. In fact, such a coalition is not exceptional at all. Coalition of capitalist elites and realtors in Atlanta, USA with a motive to increase auto-mobility and property values portrayed a five-minute walk to a corner store, to buy milk, as a case of 'inferior mobility' compared to a 10minute, five-mile drive (Henderson, 2004:203). Similarly, Mauritius, a developing country with low level of car use and no large car, or oil industry, sought for "developed world solutions for developing world" as the "pro-roads lobby ... [forced] the Government to encourage the growth in car use by equating more cars with greater prosperity and social progress (Enoch, 2003:297-303). Pucher et al. (2005:196) also identify political influence of the automobile and highway lobbies as a formidable obstacle to improved transport policies in India.

Now the question is what is the reality that keeps all these actors bound together?, or how does the coalition sustains? It can be explained in following ways. 


\subsection{A strange - yet not uncommon - elite and middle class mindset against rickshaws}

Harvey (1982, 1996), Logan and Molotch (1987) and others highlighted the role of values of particular class in framing urban politics. Actors with a 'discriminatory mindset' (E\&B, 2005:4) informally coalesce in favour of the urban elite and middle class (Vasconcellos, 2001; Tiwari, 2001). Authors have also observed a 'strange' tendency by the different section of citizens, even including rickshaw users, of Dhaka which is 'famous' for rickshaw. They blame rickshaws and rickshaw-wallas for urban ills. An expert explains the reason: "In Dhaka we have no hierarchy in urban roads and associated land-use control. So rickshaws are bound to get into conflict with faster modes. Rickshaw-wallas, for most of whom this is their first job in Dhaka, suddenly and directly drift into a major thoroughfare from a local/neighbourhood road. This makes road users, including elite decision makers and middle class car users, disturbed and annoyed. Traffic policemen are often blamed by them for not controlling rickshaws. Ultimately traffic police find rickshaw-wallas at hand to ventilate their wrath in the road where almost no one follows traffic rules"(Interview 7). The elite-middle class mindset more vividly appears when DTCA boss terms the beneficiaries of the rickshaw trade 'the criminal elements' with a call to 'target them' (DS, 2003). Another example of elite discrimination against rickshaws and rickshawwallas is found in Baridhara, Dhaka - the diplomatic zone - where the home owners and residents society has put restriction on the lungi-[local male wear]-clad rickshaw-wallas from entering the area (DS, 2013). This explains, despite studies arguing for a separation of NMT and MT and for no numerical control of rickshaws (STP 2005b:17), why they are being banned. A retired professor recalls, "I have never seen in my professional life any individualized transport using decision-maker talking in favor of rickshaws" (Interview 10). A similar observation comes from a member of the Advisory Committee of STP: "after attending several meetings, I was convinced that the ultimate purpose was to establish the need for investment intensive interventions like flyovers, expressways under the coating of a scientific study" (Interview 11).

In fact, this is a 'new politics' (Harris, 2006) by the middle/high class for "accessing urban services" (Hossain, 2013:79). "There is almost certainly a lack of interest by engineers... [favoring]... more technically rewarding road and bridge design. Police often focus on the difficulties of enforcing NMT routes and on the lack of respect of cyclists for traffic regulations. Similarly, the richer and more politically influential classes are likely to be car users and to have a vested interest in reducing the nuisance offered by slow-moving and congesting NMT" (WB, 2002:127). In Mumbai, India the "affluent sections of society systematically overlook peoplecentred approaches and exclude the welfare concerns of the poor" by vigorously promoting road-based, privatised, vehicular transport infrastructures (Mumbai, Low \& Banerjee-Guha, 2003:8).

In a weak democracy, lower middle class and the poor majority are heard only during "the democratic electoral process ... However, after the elections, and during policy making, politicians are dominated by upper-middleclass technocrats and experts with different concerns" (Thynell et al., 2010:428). B\&E (2005b:22) show that an elected parliament member "betrayed" his election pledge for lifting ban on rickshaws in his constituency as rickshaw-wallas were not his direct clients. 
Gallagher (1992) shows that in Dhaka rickshaw business is confined to 'non-elites'. During the interviews none could name any elite investor in the rickshaw business. So bans remain unchallenged by organized business chambers. On the contrary, contemporary to rickshaw ban in 2002 was a ban on two-stroke auto-rickshaws resulting introduction of four-stroke auto-rickshaws exclusively imported by associates of the then ruling party high-ups (Interview 5). Similar is the case in Jakarta. Hook and Replogle (1996:82) argued that the becak industry, controlled by very small entrepreneurs, was "not profitable to any of the President's relatives". Moreover, after the ban, the Jakarta City Council introduced motorized tuk-tuk (manufactured by the President's family firm) indicating 'presidential approval' to becak ban!

\subsection{Weak and military government - a vehicle to pursue anti NMT decisions}

If a government does not have strong political or economic base, it is highly susceptible to 'turn into a vehicle to pursue material goals' as stated by Molotch (1993). Such weak government will 'grab' any project that fetches money or increase its image to the people, particularly elite and middle class. Since NMT is seen as 'primitive and outmoded' (Hook \& Replogle 1996:82) and an 'insult to decision-makers' (Whitelegg \& Williams, 2000:17), banning NMT reaps a politico-financial gain. Moreover, transport infrastructure projects are usually investment intensive. Thus intermediaries and officials even create unnecessary demand for foreign aid through such projects (Sobhan, 2007). E\&B (2005:4) allege that "STP is mainly designed to satisfy the needs of the project hungry bureaucrats". A former Transport Minister validates these arguments: "There is a trio of Prime minister, Foreign Minister and Finance Minister who usually do not or cannot say no to any option for getting foreign grant, loan especially when it is large and at low cost. Therefore often agencies are interested to formulate projects which will bring in dollars, but not quality improvement or well-being to the people. It also creates a sort of competition among the government agencies to show competence in bringing in foreign financed projects" (Interview 12).

Military governments, Silva (1995:200) shows, use "technocratic" politics to highlight technical solutions and ignore the actual diagnosis of problem. Interstingly, NMT bans are common features of several military governments: General Ayub Khan- in Karachi, General Ershad (first rickshaw ban) in Dhaka, Field Marshal Sarit in Bangkok. Rahman et al. (2009) terms rickshaw ban a same mistake like becak ban by Indonesian General Suharto.

Weak governments are also little interested to build the inherent capacity of specialized agencies or local government bodies. These rulers partially replace traditional bureaucracy with 'flexible'/short-term advisors, consultants and focuses on, "political demobilisation and elite politics as the means to consolidate democracy" (Zunino, 2006:1835). An official of DTCA complaints his organization is weak by born as (i) it has always been headed by a deputed bureaucrat instead of a technical person in the field and is inadequately staffed which

makes it dependent on external consultants who in many cases come from abroad and are directly selected by donors (Interview 13). Likewise, a centre-dependent local government fails to take local initiative for NMT (WB, 2002:127). 
Weak and military government does not also 'quarrel' or negotiate with military, paramilitary or other organised forces to realise any common good: "Initially buses were plying on the NMT free road as per plan. However, they were withdrawn by the owners and their association gradually and government could take no measure. Besides, we repeatedly tried to find an opening though BDR [Para-military force mostly administered by army high-ups] headquarters for the movement of general people. But all in vain! BDR was not interested and government even ignored the whole NMT plan!" (ibid).

\subsection{A productive coalition of actors - an urban regime}

Following 'regime theory' (Shefter, 1985; Elkin, 1987; Mollenkopf, 1983; Stone, 1989, 1993) a relatively stable, cross-sectoral, informal and productive (Stone, 2005, 2001) coalition of several actors is found in case of promoting auto-mobility in Dhaka. In this coalition actors are donor countries, donor agencies, donor bureaucracy, local bureaucracy, local decision makers and ruling class and they are active in different scales and levels (Figure 3).

Transport concentrates major capital investment in less developed countries (Leinbach, 1995); accounting as much as 40\% (Button, 1993). So donor countries and donor agencies are always interested to make big investment in building transport infrastructure or exporting autos. Midgley (1994:4-6) shows that during the 1990 s, $60 \%$ of WB aid went to the road sector and less than $\%$ to NMT. Hook and Replogle (1996:70) claim that facing gradual decrease of auto exports to USA the Japanese government concentrated on expanding the market into East and Southeast Asia; Thailand imported 80\% of its motor vehicles from Japan and received Japanese investment of US\$135, US\$283.5 and US\$500 (pledged) million in 1963-1986, 1987-91 and 1997 2002 respectively. Japan is also the primary source of imported (reconditioned) autos for Bangladesh.

Interests of donor and government bureaucracies mingle while formulating projects. Donor bureaucracy - to reduce their work load - usually tries to reach target for aid disbursement in Bangladesh by three/four large projects (Sobhan, 2007:172). Again, as already stated, fetching a big project is encouraged by the government and increases performance record to the local bureaucrat. So a 'collusive' coalition between donor and recipient bureaucracies emerge to inflate the size of the projects and pass it anyhow. But NMT projects are by nature much smaller ones. The interests of government officials and businessmen merge in expensive infrastructure, mega-projects as those are politically easier to implement than simple pavement improvements (Hook 2003:31). As a result, the ruling class and bureaucrats usually approve even misguided anti-NMT policies (E\&B, 2005:4). Higher import duties on bicycles (170\%) and its parts (also used for rickshaws) than that for motorcycles and reconditioned cars (Replogle, 1991:12), is another example. The statement, made two decades ago holds true even today. 


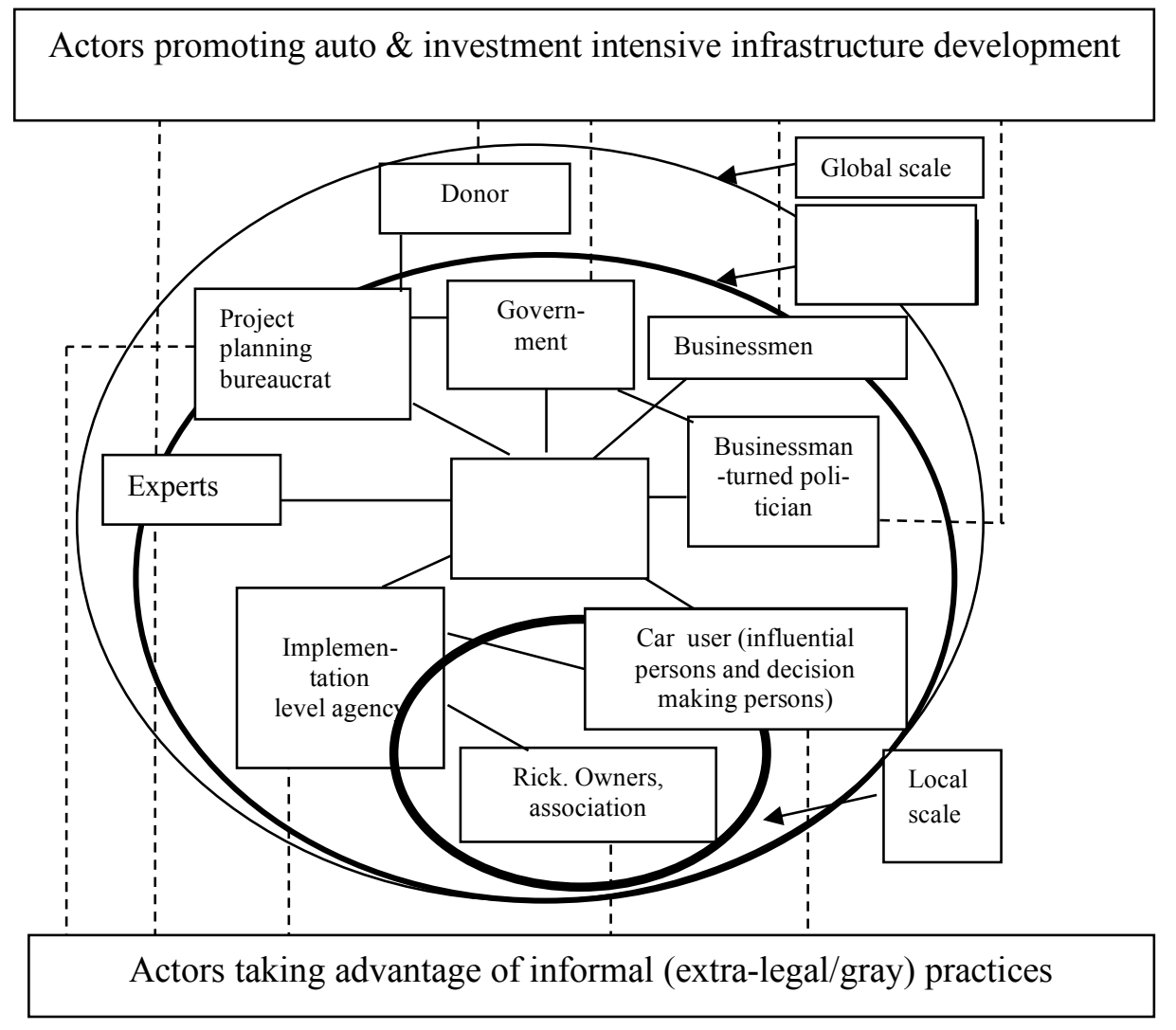

(Keys: Arrows - scale of actions; solid line - who is connected to whom, dotted line- linkages of actors with respect to broad theoretical contexts)

Figure 3: Dynamics of 'Glocal' coalition against rickshaws Source: Authors' elaboration

\subsection{The Politics of informality}

As already stated, taking advantages of 'gray spaces' policemen or officials bend some rules for illegal 'number plate' holders in exchange for 'protection fees'. Sometimes industry insiders, owners, also instigate bans to reap some calculated advantages. Also in Thailand, often "operators have to rely on local mafia, or they themselves may be [so]" (Ratanawaraha, n.d.).

The execution of ban on rickshaw is also kept in a 'gray space'. Earlier DMP used to announce their plan on ban and restriction in advance and execute the decision during long public holiday like the Eid vacation (Interview 8). Now there is no announcement. "One day I found one of the intersections in my daily travel path closed for rickshaws in the evening, which was open in the morning" exclaimed a regular rickshaw rider (Interview 14). Experts and citizen activist think that perhaps it is a strategy by DMP to keep the restriction officially unnoticeable and flexible. 
There is also a subjective flexibility for certain users (students, guardians with school children etc.) (ibid). Such flexibility again had been found to be contemporary to litigation by a female advocate (Writ, 2011) on the ground of her own and school-going child's mobility problems in absence of any other alternatives. While giving its rule, the High Court ordered DMP to provide a list of all such restricted intersections and to make footpaths free for pedestrian movement (Rule, 2012). An amicus curie for these writ and rule revealed that although the court understood the importance of rickshaws, feared withdrawing the ban would flood Dhaka by rickshaws (Interview 15). So the rule of the court may be considered as another example of "state facilitated informal practice" (Hossain, 2013:55). However, such stance by the court on one hand indicates need for a just mobility framework and on the other hand shows of what Hoque (2011:119) called "endeavouring to balance between the business/private interest and the public interest or public duties".

Such attempts to ban and restrict rickshaws in Dhaka are the best examples of 'day-to-day planning' (Nilsson, 2007) and 'tyranny of small decisions' (Odum, 1982). These moves also undermines the effort of other actor involved. A concerned official discloses: "we have completed the study and design for the NMT lane in one road and are about to call for tender for implementation. But to our utter surprise DMP has recently banned rickshaw in that road" (Interview 16).

\section{Conclusion}

The article highlights that rickshaw is the single highest passenger carrying mode in Dhaka. It is the prime NMT mode as well. Yet, since eighties there have been organized effort to off-limit Dhaka roads to this mode, initially at the whims of individuals and later on under the cover of policies, plans and scientific studies. Interestingly, all the plans and studies are financed by donors like the World Bank, UNDP, JICA etc. But actors involved in decision making - with "strategic", "hidden", "direct/active" and "passive" involvements - include both institutions and individuals; policy makers and implementers. They have their scales of operation from local (neighbourhood and city), national to global. Hence, the article claims that a 'Glocal' (global plus local) coalition exists in this regard. As what is claimed by Mollenkopf (1983), Stone $(1982,1989,1993)$ the idea that a single elite group is instrumental in making decision against rickshaws is nullified and a 'Glocal' coalition of actors with common interest is identified in this paper. It has been shown that the dynamics of bans and restrictions of rickshaws in Dhaka is a part of a global trend towards auto-oriented development, in general, and anti-NMTs development, in particular. Finally, the ban is also a part of a blue-print to help secure a place for national and international capital in costly transport infrastructure. So, politics of (im)mobility works through a coalition of global and local actors grouped together in a 'gray' policy and implementation space, knowingly or unknowingly to extract some 'extra-legal' benefits - small-big, administrative-business, political-personal, bureaucratic-technocratic, etc., despite occasional differences. So, a relatively stable, crosssectoral, informal and productive 'urban regime' for motor-cars exists in Dhaka. By contrast, the mass consumer of rickshaw service remains disorganised and rickshaw-wallas still have no single organization to represent their interests. Thus an 'organised encroachment of the powerful' (Hackenbroch \& Hossain, 2012) in presence of a weak government makes the poor rickshaw-wallas the weakest link in the chain, an easy prey to eviction. 'Muddling' (Lindblom, 1979) through these actions ultimately results 'circularity' or 'controlled 
volitions' (Lindblom, 1977) i.e. people are persuaded to demand only what goes in favor of beneficiaries of auto-mobility. The worst consequence of such actions ultimately makes alternative options for urban 'mobilities' limited, if not seized.

A more transparent form of governance, a stronger and more imaginative local government (Dávila, 2009), a more highly qualified bureaucracy and a better informed public could conceivably turn the pro-growth investment into a pro-people movement and ensure competition in urban transport market while preventing what Replogle (1991:13) termed "monopoly and oligopoly of particular modes and service providers". Further research is needed to examine the responses of communities to such top-down intervention, gauge the socioeconomic and environmental losses arising from rickshaw ban and restriction as well as its impact on land-use and housing. Other research questions could be why the recent ban decisions are being successful, while initial once were withdrawn; why rickshaw owners and associations are reluctant to press for demand for their livelihood making industry.

\section{Acknowledgements}

A version of this paper was presented at the 32nd International Geographical Congress 2012, Germany. Authors are grateful to the Commonwealth Commission (UK), and UCL (Graduate School and DPU), UK. We also acknowledge the anonymous reviewers for their comments and suggestions.

\section{References}

1 Ahmed, Qureshi Intikhab and Shi Ye, Huapu Lu (2008) Urban transportation and equity: A case study of Beijing and Karachi, Transportation Research Part A 42: 125-13

2 B\&E-Bari, M. M. and Efroymson, D. (2008) Colonial bureaucracy and sustainable transport developments in Bangladesh, WBB Trust, Dhaka

3 - (2005a) Efficient Use of Road Space and Maximisation of Door-to-Door Mobility: Suggestions for Improvements in Dhaka. WBB Trust, Dhaka

4 -(2005b) Rickshaw Bans in Dhaka City: An Overview of the Arguments For and Against. Roads for People, Dhaka

5 Begum, Sharifa \& Sen, Binayak. (2004). Unsustainable Livelihoods, Health Shocks and Urban Chronic Poverty: Rickshaw Pullers as a Case Study, SSRN Electronic Journal, 10.2139/ssrn.1754402

6 Bromley, R. (2004) Power, property and povety: Why De Soto's "Mystery of Capital" cannot be solved, in Roy, A. and AlSayyad, N. (eds) Urban Informality- Transnational perspectives from the Middle East, Latin America and South Asia, Lanhum, USA: Lexington Books, 271-288

7 Button, K. (1993) Transport economics, 2nd ed. Elgar, Aldershot

8 Cresswell, T. (2010) Towards a politics of mobility, Environment and Planning D: Society and Space, 28, $17-31$

9 Dahl, A. (1961) Who governs? Democracy and power in an American city, Yale University press, New Haven, CT

10 Dávila, J. D. (2009) Being a Mayor: Four views from Colombia, Environment and Urbanization, 20(1), 37 57 
11 De Soto, H. (2000) The Mystery of Capital, New York: Basic Books

12 De Soto, H. (1989) The Other Path: The Invisible Revolution in the Third World, New York: Harper and Row

13 DS (2013) Entry to Baridhara: ban slapped on lungi clad rickshaw-pullers, The Daily Star(DS) , $3^{\text {rd }}$ April, 2013

14 - (2012) Rickshaws clog city, The DS, 29th March, 2012, Dhaka

15 -(2003) Real beneficiaries of rickshaw trade are criminal elements, DTCB director alleges, The DS, 8th September, 2003, Dhaka

16 DSM Consultants (2006) Impact Assessment of DUTP 'After Project', Final Report submitted to Dhaka Transport Co-ordination Board (DTCB), Government of Bangladesh (GoB), by the DSM (Design, Supervision and Monitoring) Consultants, Bangladesh

17 DITS (1994a) Greater Dhaka Metropolitan Area Integrated Transport Study-Final Report: Vol 1-Database and Immediate action plan, prepared by PPK, Canada and DDC, Bangladesh for PC, GoB and UNDP

18 (1994b) Greater Dhaka metropolitan area integrated transport study-Final Report: Vol 2-Strategic decisions, prepared by PPK Consultants Pvt Ltd, Australia, Delcan International Cooperation, Canada and Development Design Consultants (DDC), Bangladesh for Planning Commission (PC), GoB and UNDP

19 Elkin, S. I. (1987) City and Regime in the American Republic, University of Chicago press, Chicago

20 Enoch, Marcus P. (2003) Transport practice and policy in Mauritius", Journal of Transport Geography, 11: 297-30

21 E\&B-Efroymson, D. and Bari, M.M (2005) Improving Dhaka's Traffic Situation, Lessons from Mirpur Road, WBB Trust, Dhaka

22 Feagin, J. R. and Smith, M. P. (1987) Cities and the new international division of labor: an overview, in Smith, M. P. and Feagin, J. R. (eds) The Capitalist City, 3-34, Oxford, UK and Cambridge, MA: Basil Blackwell

23 Gallagher, R. (1992) The Rickshaws of Bangladesh, University Press Limited, Dhaka

24 GoB (2004) The National Land Transport Policy-2004, MOC, GoB, Dhaka

25 - (1999) Project Proforma-PP (GDTPCB's Component), Dhaka Urban Transport Project, Greater Dhaka Transport Planning and Co-ordination Board (GDTPCB), GoB, Dhaka

26 Gondo, Tendayi (2010) Towards a Sustainable Urban Transport System: An Analysis of the Epistemology and Planning Policy Direction for Non-Motorized Transport in Ethiopian Cities The IUP Journal of Infrastructure, VII(3):58-78

27 Goyal, Vedant and Asija, Navdeep (2015) Fazilka Ecocabs: World's First Dial-a-Rickshaw Scheme - Experiences and Lessons, Case Studies in Sestainable Urban Transport No. 09, GIZ, in http://www.indiaenvironmentportal.org.in/files/file/Fazilka\%20Ecocabs.pdf accessed on $20^{\text {th }}$ July, 2016

28 Gwilliam, K. (2003) Urban transport in developing countries, Transport Reviews, 23(2), 197-216

29 Hackenbroch, K. and Hossain, S. (2012) "The organised encroachment of the powerful"-Everyday practices of public space and water supply in Dhaka, Bangladesh, Planning Theory \& Practice, 13(3), $397-420$

30 Harris, J. (2006) Power Matters: Essay on Institutions, Politics, and Society in India, New Delhi: Oxford University Press

31 Harvey, D. (1996) Justice, Nature, and the Geography of Difference, Malden, MA: Blackwell

32 Harvey, D. (1982) The Limits to Capital, Oxford, UK: Blackwell

33 Hasan, Md. Musleh Uddin, (2013) Unjust mobilities: The case of rickshaw bans and restrictions in Dhaka, unpublished $\mathrm{PhD}$ thesis, DPU, University College London, UK. 
34 Henderson, J. (2004) The Politics of Mobility and Business Elites in Atlanta, Georgia, Urban Geography, 25(3), 193-216

35 Hook, W. (2003) Sustainable transport-A source book for policy-makers in developing countries: Module 3d-Preserving and expanding the role of non-motorised transport, GTZ-Transport and Mobility Group, GTZ, Germany

36 Hook, W. and Replogle, M. (1996) Motorization and non-motorized transport in Asia-Transport system evolution in China, Japan and Indonesia, Land use Policy, 13(1), 69-84

37 Hossain, Maruf \& Susilo, Yusak. (2011). Rickshaw Use and Social Impacts in Dhaka, Bangladesh. Transportation Research Record, Journal of the Transportation Research Board, 2239:74-83. 10.3141/2239-09.

38 Hoque, R. (2011) Judicial activism in Bangladesh: A golden mean approach, Cambridge Scholars, Newcastle-upon-Tyne

39 Hossain, S. (2013) Contested Water Supply: Claim Making and the Politics of Regulation in Dhaka, Bangladesh, Stuttgart: Franz Steiner Verlag

40 Imran, Muhammad \& Low, Nicholas (2003) Time to Change the Old Paradigm: Promoting Sustainable Urban Transport in Lahore, Pakistan, World Transport Policy \& Practice, 9(2):32-39

41 Islam, Nazmul (2015) A Study on Material Culture in Dhaka - Rickshaw, A Motion Craft, Master of Architecture thesis, McGill University

42 Jensen, A. (2011) Mobility, Space and Power: On the Multiplicities of Seeing Mobility, Mobilities, 6(2), $255-271$

43 JICA (2010) Dhaka Urban Transport Network Development Study (DHUTS)-Final Report, Submitted to DTCB, MoC, GoB, Dhaka

44 Kalabamu, F. T. (1987) Rickshaws and the Traffic Problems of Dhaka, Habitat International,. 11(2), 123-131

45 Khayesi, M., Monheim, H. \& Nebe, Johannes Michael (2010) Negotiating "Streets for All" in Urban Transport Planning: The Case for Pedestrians, Cyclists and Street Vendors in Nairobi, Kenya, Antipode, 42 (1):103-126

46 Leinbach, Thomas R. (1995) Transport and third world development: review, issues, and prescription, Transportation Research-A, 29(5), 337-344

47 Lindblom, Charles E. (1979) Still muddling, not yet through, Public Administration Review, 39(6), 517526

48 Lindblom, Charles E. (1977) Politics and Markets: The World's Political-Economic Systems, New York: Basic Books

49 Logan, J. R. and Molotch, H., (1987) Urban Fortunes: The Political Economy of Place, Berkeley, CA: University of California Press

50 Low, Nicholas \& Swapna Banerjee-Guha (2003) The Global Tyranny of Roads: Observations from Mumbai \& Melbourne, World Transport Policy \& Practice, 9(2):5-17

51 Metro (2012) Record number of Tube passengers provide welcome Olympic retail boost, The Daily Metro, 6th August 2012, London in http:/www.metro.co.uk/olympics/907612-record-number-of-tubepassengers-provide-welcome-olympic-retail-boost\#ixzz29B14hvz7, accessed 28th September, 2012

52 Majumder, J., Haque, M. S. and Alam, M. J. B. (2009) Transport Crisis in Dhaka City, in Alam, M.J.B. (ed) Transport Problems in Dhaka City: Issues, Concerns and Policy Options, Department of CE, BUET, Dhaka

53 Midgley, P. (1994) Urban transport in Asia: an operational agenda for the 1990s, Technical paper no.224, Asia Technical Department Series, The World Bank, Washington 
54 Mollenkopf, J. H. (1983) The contested city, Princeton University press, Princeton, NJ

55 Molotch, H. (1993) The political analysis of growth machines, Journal of Urban Affairs, 15(1), 29-53

56 Nayadiganta (2012) Earning millions buy illegal number plates (In Bangla- Vua number plate diye koti taka uparjon), The Daily Nayadiganta, 20th September, 2012, Dhaka

57 New Age (2005) No aid if rickshaw pullers are not protected, The daily New Age, 9th February, 2005, Dhaka

58 Nilsson, K. (2007) Managing complex spatial planning processes, Planning Theory and Practice, 8, 431447

59 Odum, W. (1982) Environmental degradation and the tyranny of small decisions, Bio Science, 32, 728729.

60 Pucher, J., Korattyswaropam, N., Mittal, N. and Ittyerah, N. (2005) Urban transport crisis in India, Transport Policy 12, 185-198

61 RAJUK (2015) Dhaka Structure Plan, Draft, Rajdhani Unnayan Kartripakha (Capital Development Authority), Dhaka

62 Rahman, Mamun M., D'Este, G. and Bunker, Jonathan M. (2009) Is there a future for non-motorized public transport in Asia? In: Proceedings of the 8th International Conference of the Eastern Asia Society for Transportation Studies (EASTS), 16 - 19 November 2009, Surabaya, Indonesia

63 Ratanawaraha, A. (n.d.) Informal mobility is here to stay, Trendnovation Southeast, Issue 14, Newsletter is published by Noviscape Consulting Group (NCG), in http://trendsoutheast.org/2011/all-issues/issue14/informal-mobility-is-here-to-stay, accessed on 22nd Sep 2012

64 Ravi, R. (2012) Passenger Cycle Rickshaws in NCR-A Profile, paper presented in the Workshop on Rickshaws held at the Indian Institute of Technology, Delhi, 11-12 July 2012

65 Replogle, M. (1991) Non-motorized vehicles in Asia: Lessons for sustainable transport planning and policy, World Bank Technical Report 162, Environmental Defence Fund, Washington D.C., USA

66 Richardson, T. and Jensen, O. B. (2008) How mobility systems produce inequality: Making mobile subject types on the Bangkok sky train, Built Environment, 34(2), 218-231

67 Roy, A. (2004a) The gentleman's city: Urban informality in the Calcutta of the new communism, in Roy, A. and AlSayyad, N. (eds) Urban Informality- Transnational perspectives from the Middle East, Latin America and South Asia, Lanhum, USA: Lexington Books, 289-318

68 Rule (2012) Rule dated 5th March 2012, Writ Petition no 7132 of 2011 and Writ Petition 8619 of 2011 in the Supreme Court of Bangladesh, High Court Division, Dhaka (pending full hearing/judgment)

69 Sager, Tore (2006) Freedom as Mobility: Implications of the Distinction between Actual and Potential Travelling, Mobilities, 1(3), 465-488

70 Sassen, S. (1991) The global city, New York, London, Tokyo, Princeton, NJ: Princeton University Press

71 Sen, Jai (1996) The Left Front and the 'Unintended City': Is a Civilised Transition Possible?, Economic and Political Weekly, 31(45/46), Nov. 9-16, 2977-2982

72 Shefter, M. (1985) Political Crisis, Fiscal Crisis: The Collapse and Revival of New York City, New York: Basic Books

73 Sheller, M. (2008) Mobility, freedom and public spaces, in S. Bergmann and T. Sager (eds) The Ethics of Mobilities: Rethinking Place, Exclusion, Freedom and Environment, 25-38, Ashgate, Aldershot

74 Sietchiping, R., Permezel,M. J. and Ngomsi, C. (2012) Viewpoint: Transport and mobility in sub-Saharan African cities: An overview of practices, lessons and options for improvements, Cities, 29, 183-189

75 Silva, E. (1995) Intellectuals, technocrats, and politics in Chile: from global projects to the 'management of things', in Galjart B. and Silva, P. (eds) Designers and Development: Intellectuals in the Third World, 190-212, Leiden University press, Leiden 
76 Sobhan, R. (2007) Collected Works of Rehman Sobhan-Challenging injustice-The odyssey of a Bangladeshi economist, Vol-1, Centre for Policy Dialogue, Dhaka

77 Stone, C. N. (2005) Looking Back to Look Forward: Reflections on Urban Regime Analysis, Urban Affairs Review, 40(3), 309-341

78 Stone, C. N. (2001) The Atlanta experience re-examined: The link between agenda and regime change, Urban Affairs Review, 25(1), 20-34

79 Stone, C. N. (1993) Urban regimes: A political economy approach, Journal of Urban Affairs, 15(1), 1-28

80 Stone, C. N. (1989) Regime politics: Governing Atlanta 1946-1988, Lawrence: University Press of Kansas

81 Stone, C. N. (1982) Social stratification, nondecision-making, and the study of community power, American Politics Quarterly, 10(3), 275-302.

82 STP (2005a) Working Paper 7- Survey Result, Strategic Transport Plan for Dhaka prepared by Louis Berger Group (LBG) and Bangladesh Consultant Ltd (BCL) for DTCB, GoB, Dhaka

83 - (2005b) The Urban Transport Policy--Final Report, Strategic Transport Plan for Dhaka, prepared by LBG and BCL for DTCB, GoB, Dhaka

84 Strom , E. (1996) In search of the growth coalition: American urban theories and the redevelopment of Berlin, Urban Affairs Review, 31, 455-481

85 Thynell, M., Mohan, D. and Tiwari, G. (2010) Sustainable transport and the modernisation of urban transport in Delhi and Stockholm, Cities, 27, 421-429

86 Tiwari, Geetam (2002) Urban Transport Priorities- Meeting the Challenge of Socio-economic Diversity in Cities, a Case Study of Delhi, India, Cities, 19(2):95-103

87 Tiwari, G., 2001. Pedestrian infrastructure in the city transport system: Delhi case study. World Transport Policy and Practice 7(4), 13-18

88 UN ESCAP (1997) Background papers of non-motorised transport in Dhaka (Draft), Integration of nonmotorised transport in the urban transport system of Dhaka, Bangladesh

89 Vasconcellos, E., 2001. Urban Transport, Environment and Equity: The Case for Developing Countries, Earthscan, London

90 Whitelegg, J. and Williams, N. (2000) Non-motorised Transport and Sustainable Development: Evidence from Calcutta, Local Environment, 5(1), 7-18

91 WB-World Bank (2005) Implementation Completion Report (IDA 31630) On A Credit in the amount of US\$177 Million To the People's Republic of Bangladesh For Dhaka Urban Transport Project, Report no-34544-BD

92 _(2002) Cities on the move: a World Bank urban transport strategy review, World Bank, Washington DC

93 Writ (2011) Writ Petition no 7132 of 2011 in the Supreme Court of Bangladesh, High Court Division, Dhaka (pending full hearing/judgment)

94 Yiftachel, Oren (2009) Theoretical Notes On 'Gray Cities': The Coming Of Urban Apartheid?, Planning Theory, 8(1), 87-99

95 Zacharias, John (2012) Resisting motorization in Guangzhou, Habitat International, 36(1), 93-100

96 Zunino, Hugo M. (2006) Power Relations in Urban Decision-making: Neo-liberalism, 'Techno-politicians' and Authoritarian Redevelopment in Santiago, Chile, Urban Studies, 43(10), 1825-1846

\section{Interviews made during field work in 2012}

97 Interview 1: Interview with a DCC official of the Wheel Tax Department in charge of rickshaws, vans etc.

98 Interview 2: Interview with a rickshaw (garage) owner at Modhubag, Dhaka who identified himself a "neither large nor small" rickshaw owner. 
99 Interview 3: Interview with a rickshaw-walla at Shyamoli, who earlier could cross the road with his rickshaw

100 Interview 4: Interview with a retired professor of Department of Urban and Regional Planning at Bangladesh University of Engineering and Technology (BUET), who was President of a professional body for more than once

101 Interview 5: Interview of a citizen activist from Work for Better Bangladesh Trust, Dhaka

102 Interview 6: Interview with another rickshaw-walla at Kalabagan area, near Sukrabad

103 Interview 7: Interview with a Professor of Department of Civil Engineering at BUET, who has worked as adviser to many government projects and also as consultants in many transport projects

104 Interview 8: Interview with a Professor of Urban and regional Planning Department at Jahangirnagar University, Savar, Dhaka

105 Interview 9: Interview with a journalist of a national Bangla daily who has been closely monitoring and reporting on transport issues in Dhaka since 1996

106 Interview 10: Interview with a retired professor of Department of Urban and Regional Planning at BUET)

107 Interview 11: Interview with a former Professor of Department of Urban and Regional Planning at BUET, who was also a member of Technical Management Committee (TMC) for STP.

108 Interview 12: Interview with a former transport minister during the period of 1996-2001

109 Interview 13: Interview with a senior planning official of Dhaka Transport Coordination Authority (DTCA) who has been here since its inception

110 Interview 14: Interview with a rickshaw user at Bijoynogar, Dhaka

111 Interview 15: Interview with a senior professor of the Department of Urban and Regional Planning, who was also the President of a profession body

112 Interview 16: Interview with a senior transport engineer of DTCB

Internet Materials: all accessed on 10 March, 2017

113 Internet 1: http://indiatoday.intoday.in/story/the-rickshaw-capital/1/303573.html,

$114 \quad$ Internet 2: http:/www.sydneycyclist.com/forum/topics/the-rickshaw-capital-of-theworld? commentId $=1321712 \% 3$ AComment $\% 3$ A682702,

115 Internet 3:http://www.businesshabit.com/2016/09/rickshaw-capital-of-world.html,

116 Internet 4:http://planetden.com/architecture/rickshaw-capital-world-dhaka, 